\title{
Implementasi Kebijakan Pemerintah Daerah tentang Kemampuan Baca-Tulis Al-Qur'an
}

\author{
Hayadin
}

\begin{abstract}
This case study research aims at finding the implementation of Local Government's policy on the readingwriting the Qur'an. The research is carried out in a number of regions that have policy on the reading-writing the Qur'an, i.e.: Pekanbaru, Kampar, Indramayu, Tasikmalaya, Serang, Cilegon,

Dr. Hayadin, M.Pd adalah peneliti Puslitbang Pendidikan Agama dan Keagamaan - Badan Litbang dan Diklat Kementerian Agama RI

Naskah diterima 15 Januari 2011. Revisi pertama, 30 Januari 2011, revisi kedua,15 Februari 2011 dan revisi terakhir 25 Maret 2011. Banjarmasin, Banjar, Maros, Gowa, Gorontalo, and East Lombok. The research outcome explains that the Local Government's policy on the reading-writing the Qur'an is set out in the Local Regulation, Regental Regulation, Call Out of the Regent, Governor's Instruction, and Instruction of Education Office Head. The implementation of the policy is executed by a certification obligation of the competency on the reading-writing the Qur'an as an acceptance requirement for a new student at the educational levels of junior
\end{abstract}


high school and senior high school as well as vocational school.

Kata Kunci: local Government's policy, the reading-writing the Qur'an, certification obligation

\begin{abstract}
Abstrak
Penelitian studi kasus ini bertujuan untuk mengetahui implementasi kebijakan Pemerintah Daerah tentang baca-tulis Al-Qur'an. Penelitian dilakukan pada sejumlah daerah yang memiliki kebijakan tentang baca-tulis Al-Qur'an, yakni: Pekanbaru, Kampar, Indramayu, Tasikmalaya, Serang, Cilegon, Banjarmasin, Banjar, Maros, Gowa, Gorontalo, dan Lombok Timur. Hasil penelitian menjelaskan bahwa kebijakan Pemerintah Daerah tentang baca-tulis Al-Qur'an dituangkan dalam Peraturan daerah, Peraturan Bupati, Himbauan Bupati, Instruksi Gubernur, dan Instruksi Kepala Dinas Pendidikan. Implementasi kebijakan tersebut dilaksanakan melalui adanya kewajiban sertifikasi kemampuan baca-tulis Al-Qur'an sebagai persyaratan penerimaan siswa baru pada jenjang pendidikan menegah pertama dan jenjang menengah atas, serta sekolah kejuruan.
\end{abstract}

Kata Kunci: kebijakan Pemerintah Daerah, baca-tulis al-Quran, kewajiban sertifikasi

\title{
I. PENDAHULUAN
}

\section{A. Latar Belakang}

Kemampuan baca tulis Al-Qur'an merupakan salah satu dasar utama dalam pembelajaran pendidikan agama Islam di sekolah. Setiap siswa muslim diharuskan untuk dapat membaca dan menulis Al-Qur'an secara baik, sebagai alat utama mempelajari Agama Islam baik di sekolah ataupun secara mandiri di luar sekolah. Karena setiap dalil naqli yang bersumber dari Al-Qur'an dan Al-Hadits lebih mudah dipelajari dan dimengerti dengan kemampuan baca-tulis Al-Qur'an. Oleh karena itu, hampir seluruh sekolah dan madrasah menerapkan proses pembelajaran baca - 
tulis Al-Qur'an sebagai salah satu bagian dari materi dan kurikulum pendidikan agama Islam di sekolah.

Fungsi kemampuan baca-tulis Al-Qur'an yang penting seperti tersebut di atas juga telah mendorong masyarakat, orang tua, dan berbagai lembaga social keagamaan untuk menyelenggarakan kegiatan pendidikan dan pembelajaran baca-tulis Al-Qur'an. Anakanak dan pelajar juga menjadikan kebiatan belajar baca-tulis AlQur'an (mengaji) sebagai salah satu aktivitas mereka. Namun demikian, perkembangan zaman, ilmu pengetahuan dan teknologi, terutama teknologi komunikasi serta media informasi memberikan pengaruh yang besar terhadap kebiasaan dan budaya masyarakat seperti tersebut di atas. Kehadiran media hiburan dan tontonan massa telah mempengaruhi aktivitas belajar baca-tulis Al-Qur'an (mengaji). Banyak anak dan pelajar yang lebih banyak menonton televisi atau bermain game on-line ataupun off-line dari pada belajar mengaji (baca-tulis Al-Qur'an).

Pengaruh tersebut membuat prihatin banyak pihak, yakni masyarakat, tokoh agama, dan tokoh masyarakat untuk mencari solusinya. Beberapa daerah tertentu di Indonesia ada yang memandang agar supaya anak-anak dan pelajar wajib memiliki kemampuan baca-tulis Al-Qur'an. Pandangan dan keinginan tersebut pada beberapa daerah di Indonesia melahirkan kebijakan pemerintah daerah yang secara imperatif mewajibkan para peserta didik belajar baca-tulis Al-Qur'an.

Dalam perspektif pendidikan agama Islam, kebijakan yang dibuat oleh pemerintah daerah tersebut dapat dipandang positif karena dapat bersinergi dalam membina kemampuan, pengetahuan dan hasil belajar pendidikan agama Islam di sekolah. Lahirnya kebijakan pemerintah daerah seperti ini, dapat dimaknai bahwa pendidikan agama bukan lagi sepenuhnya menjadi tugas dan beban bagi guru agama di sekolah, tetapi juga menjadi tugas pemerintah daerah dan masyarakat secara keseluruhan. Jika implementasi kebijakan pemerintah daerah tentang baca-tulis AlQur'an berjalan lancar, ia akan dapat memberikan sumbangan 
yang besar bagi penyelenggaraan pendidikna agama di sekolah, dan pembentukan moral dan kepribadian bangsa yang luhur.

\section{B. Rumusan Masalah}

Berdasarkan latar belakang masalah tersebut di atas, maka rumusan masalah penelitian adalah:

1. Apa bentuk kebijakan pemerintah daerah tentang BTQ?

2. Bagaimana implementasi kebijakan pemerintah daerah tentang BTQ?

3. Apa tantangan dan hambatan implementasi kebijakan pemda tentang BTQ?

\section{Tujuan Penelitian}

Tujuan penelitian ini adalah untuk mengetahui:

1. Bentuk-bentuk kebijakan pemerintah daerah tentang BTQ

2. Proses implementasi kebijakan pemerintah daerah tentang BTQ;

3. Tantangan dan hambatan implementasi kebijakan pemda tentang BTQ

\section{KAJIAN TEORI DAN RUANG LINGKUP PENELITIAN}

\section{A. Pelajaran Baca-Tulis Al-Qur'an dan Pendidikan Agama}

Kaum muslimin meyakini bahwa membaca Al-Qur'an merupakan salah satu ibadah kepada Allah SWT dan termasuk perbuatan yang terpuji dan mendatangkan manfaat serta berkah yang banyak. Adapun membaca Al Qur'an hukumnya disyariatkan dan disunahkan untuk sebanyak mungkin membaca dan menghatamkan setiap bulan. Membaca Al-Qur'an juga merupakan salah satu rukun yang harus ditunaikan setiap kali orang (muslimin) menunaikan ibadah sholat minimal 5 (lima) kali sehari semalam (24 jam). Orang yang tidak dapat membaca Al-Qur'an tentu akan mendapat masalah dalam bacaan sholatnya. 
Rasulullah SAW menyatakan keutamaan membaca Al-Qur'an melalui sabdanya sebagai berikut: "Bacalah Al Qur'an, karena ia akan datang pada hari kiamat sebagai pemberi syafaat bagi pembacanya" (Riwayat Muslim), (Shahih Muslim, 1990: 804). Dan pada hadits yang lain dinyatakan sebagai berikut: "Barangsiapa membaca satu huruf dari kitab Allah maka baginya satu kebaikan, dan satu kebaikan itu dibalas sepuluh kali lipatnya. Aku tidak mengatakan aliflammim itu satu huruf, tetapi alif satu huruf, lam satu huruf, dan mim satu huruf."(Riwayat At-tirmidzi), (Sunan Tirmidzi, 1990: 160). Dan pada hadits yang lain beliau bersabda: "Sebaik-baik kamu ialah orang yang belajar Al-Qur'an dan mengajarkannya." (Riwayat Al-Bukhari).

Dalam perspektif pedagogik, mengajarkan baca-tulis AlQur'an kepada anak-anak memberikan manfaat yang banyak, yakni disamping sebagai dasar untuk lancar membaca Al-Qur'an sebagai sumber ajaran agama Islam, juga ia merupakan kesempatan (momentum) yang sangat baik untuk mengajarkan nilai-nila moraI, kisah-kisah religius, dan perilaku terpuji kepada anak didik. Anak-anak pada usia ini masih sangat mudah dan gampang untuk menerima apa saja yang diajarkan. Dan pendekatan pengajaran baca-tulis Al-Qur'an yang dilakukan secara kelompok, dapat menumbuhkan nilai kebersamaan dan kesetiakawanan sosial.

\section{B. Pendidikan Agama di Sekolah}

Pengertian pendidikan secara umum yang dikaitkan dengan predikat agama Islam menimbulkan pengertian baru yang secara implisit menjelaskan karakteristik-karakteristik yang dimilikinya. ${ }^{1}$ Islam sebagai suatu sistem way of life diyakini bersifat komprehensif dan telah mengatur tata kehidupan yang di dalamnya ada bidang pendidikan. Bahkan para ilmuwan Islam selalu mendefinisikan pendidikan sebagai suatu istilah yang secara Teleologis merujuk kepada Islam.

${ }^{1}$ Azyumardi Azra. 2002. Pendidikan Islam: Tradisi dan Modernisasi Menuju Milenium Baru. Jakarta: Logos, h. 4. 
Pengertian pendidikan dengan seluruh totalitasnya dalam konteks Islam inheren dalam konotosi istilah "tarbiyah, ta'lim, dan ta'dib". Pendidikan sebagai pengejawantahan dari makna ketiga istilah tersebut mengandung makna yang luas dan dalam tentang hubungan manusia dan masyarakat serta lingkungannya dalam hubungannya dengan Tuhan saling berkaitan satu sama lain. ${ }^{2}$

Dalam rumusan tujuan pendidikan nasional seperti termuat dalam sistem pendidikan nasional disebutkan bahwa "Pendidikan nasional berfungsi mengembangkan kemampuan dan membentuk watak serta peradaban bangsa yang bermartabat dalam rangka mencerdaskan kehidupan bangsa, bertujuan untuk berkembangnya potensi peserta didik agar menjadi manusia yang beriman dan bertakwa kepada Tuhan Yang Maha Esa, berakhlak mulia, sehat, berilmu, cakap, kreatif, mandiri, dan menjadi warga negara yang demokratis serta bertanggung jawab." Dan secara terminologis, sistem pendidikan nasional merumuskan pendidikan sebagai usaha sadar dan terencana untuk mewujudkan suasana belajar dan proses pembelajaran agar peserta didik secara aktif mengembangkan potensi dirinya untuk memiliki kekuatan spiritual keagamaan, pengendalian diri, kepribadian, kecerdasan, akhlak mulia."3

Sebagai cerminan dari bentuk kehidupan sosial dan budaya masyarakat Indonesia yang religius yang kemudian diadopsi secara konstitusional dalam berbagai produk peraturan perundang-undangan di Indonesia, maka pendidikan agama merupakan salah satu mata pelajaran wajib di sekolah mulai dari jenjang pendidikan dasar hingga perguruan tinggi. ${ }^{4}$ Pendidikan agama dimaksudkan untuk membentuk peserta didik menjadi manusia yang beriman dan bertakwa kepada Tuhan Yang Maha Esa serta berakhlak mulia.

\footnotetext{
2 Ibid., h. 5.

${ }^{3}$ Undang-undang No. 20 tahun 2003, pasal 1, ayat 1.

${ }^{4}$ Ibid., pasal 37, ayat 1-2.
} 
Rumusan tersebut sejalan dengan konsepsi pendidikan Islam yang disampaikan oleh para ahli pendidikan. Anshari menyatakan bahwa, Pendidikan Islam sebagai proses bimbingan (pimpinan, tuntutan, usulan) oleh subyek didik terhadap perkembangan jiwa (pikiran, perasaan, kemauan, intuisi dan sebagainya), dan raga obyek didik dengan bahan-bahan materi tertentu, pada jangka waktu tertentu, dengan metode tertentu dan dengan alat perlengkapan yang ada ke arah terciptanya pribadi tertentu disertai evaluasi sesuai dengna ajaran Islam. ${ }^{5}$ Sementara Marimba menyatakan bahwa pendidikan Islam adalah bimbingan jasmani dan rohani menuju kepada terbentuknya kepribadian utama menurut ukuran-ukuran Islam. ${ }^{6}$

Untuk mencapai tujuan tersebut dibutuhkan serangkaian ikhtiar yang sistematis dan sinergis dari berbagai pihak (orang tua, masyarakat, pemerintah dan sekolah). Masing-masing pihak dapat menunaikan tugasnya sesuai dengan kemampuan dan ruang lingkup kewenangan yang dimiliki. Para orang tua dapat mengajarkan dan mendidik anak-anaknya di rumah, masyarakat dapat menyediakan fasilitas pengamalan ibadah sebagai bentuk pendidikan praktis kepada anak didik. Pemerintah dituntut untuk menciptakan kebijakan yang kondusif bagi peserta didik dan masyarakat untuk mendalami dan mempelajari agama yang dianutnya.

Ruang lingkup Pendidikan Agama Islam di sekolah umum meliputi aspek-aspek sebagai berikut: Al Qur'an dan Hadits; Aqidah; Akhlak; Fiqih; Tarikh dan Kebudayaan Islam. Pendidikan Agama Islam menekankan keseimbangan, keselarasan, dan keserasian antara hubungan manusia dengan Allah SWT, hubungan manusia dengan sesama manusia, hubungan manusia dengan diri sendiri, dan hubungan manusia dengan alam sekitarnya.?

${ }^{5}$ Endang Saifudin Anshari. 1996. Pokok-pokok Pikiran tentang Islam. Jakarta: Usah Enterprise, h. 85.

${ }^{6}$ Ahmad D. Marimba. 1980. Pengantar Filsafat Pendidikan Islam. Bandung: Al-Ma'arif, h. 23.

${ }^{7}$ Peraturan Mendiknas Nomor 22 tahun 2006, Op.cit. 
Pada jenis pendidikan umum (SD, SMP, dan SMA/SMK) jumlah jam pelajaran dan SKS mata pelajaran pendidikan agama sangat terbatas jika dibandingkan dengan Madrasah atau pada pondok pesantren. Sementara, kandungan materi yang mesti dipelajari adalah sangat luas. Meskipun demikian, setiap lulusan Sekolah Menegah Pertama dituntut untuk memiliki seperangkat kecakapan dan kemampuan tertentu.

\section{Kebijakan Pemda tentang Baca-Tulis Al-Qur'an}

Secara yuridis, pemerintah daerah baik pada tingkat provinsi ataupun kabupaten/kota memiliki wewenang untuk menetapkan peraturan daerah dan peraturan kepala daerah. Peraturan Daerah yang biasa disingkat PERDA ditetapkan oleh Kepala Daerah setelah mendapat persetujuan bersama DPRD sebagai produk legislasi. ${ }^{8}$ Sementara itu, Kepala daerah selaku kepala pemerintahan (eksekutif) di daerah memiliki kewenangan membuat Peraturan Kepala Daerah dan/atau Keputusan Kepala Daerah. ${ }^{9}$ Kedua produk kebijakan pemerintah daerah tersebut berlaku secara sah setelah dituangkan dalam lembaran daerah dan berita daerah.

Secara prosedural teknis, kebijakan PERDA (rancangan) dapat berasal dari DPRD, gubernur atau bupati/walikota, dan masyarakat di daerah berhak memberikan masukan baik secara lisan maupun secara tertulis dalam rangka penyiapan, dan pembahasan rancangan perda tersebut. Kebijakan pemerintah daerah dalam bentuk PERDA tersebut diciptakan sebagai penjabaran lebih lanjut dari peraturan perundang-undangan yang hirarkinya lebih tinggi dalam rangka mendorong pemerintah daerah menjalankan fungsi pembangunan di daerah. Oleh karena itu, isi atau materi PERDA tidak boleh bertentangan dengan peraturan perundang-undangan yang lain atau yang hirarkinya lebih tinggi dan tidak boleh bertentangan dengan kepentingan umum.

\footnotetext{
${ }^{8}$ UU No. 32 tahun 2004, pasal 136; 1.

${ }^{9}$ Ibid., pasal 146 [1].
} 
PERDA dibentuk berdasarkan asas pembentukan peraturan perundang-undangan yang meliputi: kejelasan tujuan; kelembagaan atau organ pembentuk yang tepat; kesesuaian antara jenis dan materi muatan; dapat dilaksanakan; kedayagunaan dan kehasilgunaan; kejelasan rumusan; dan keterbukaan. Materi muatan pada PERDA harus mengandung asas: pengayoman; kemanusiaan; kebangsaan; kekeluargaan; kenusantaraan; bhineka tunggal ika; keadilan; kesamaan kedudukan dalam hukum dan pemerintahan; ketertiban dan kepastian hukum; keseimbangan, keserasian, dan keselarasan. ${ }^{10}$

Selain PERDA (peraturan daerah) dan peraturan atau keputusan kepala daerah, secara Institusional organ atau struktur pemerintahan di daerah seperti dinas dan lembaga sejenis, dapat pula mengeluarkan aturan dalam rangka mengimplementasikan PERDA dan peraturan atau keputusan kepala daerah. Kebijakan tersebut dapat berbentuk surat keputusan kepala dinas tentang tugas, pekerjaan dan kegiatan yang mesti dilaksanakan oleh aparat pemerintah di daerah.

Dari berbagai konsep dan pemikiran seperti tersebut di atas, maka secara sintetis batasan pengertian dari "Implementasi kebijakan pemerintah daerah tentang baca-tulis Al-Qur'an" praktek pelaksanaan kebijakan yang dibuat dan dikeluarkan oleh pemerintah daerah kabupaten / kota di Indonesia dalam rangka membina dan membentuk kompetensi anak didik tentang bacatulis Al-Qur'an. Adapun ruang lingkup dari penelitian ini adalah: bentuk-bentuk kebijakan pemerintah daerah yang menjadi dasar penyelenggaraan kegiatan baca-tulis Al-Qur'an di daerah; bentul implementasi kebijakan baca-tulis Al-Qur'an di daerah; dan faktor pendukung dan tantangan implementasi kebijakan baca tulis AlQur'an di daerah.

${ }^{10}$ lbid., pasal $137-138$. 


\section{METODOLOGI PENELITIAN}

Penelitian ini merupakan studi kasus (case-study) pada beberapa kabupaten/kota yang memiliki kebijakan Baca Tulis AlQur'an dengan pendekatan kualitatif, dan dilakukan pada AprilOktober tahun 2010. Lokasi penelitian di Sulawesi Selatan (Maros dan Gowa), NTB (Mataram dan Lombok Timur), Banten (Serang dan Cilegon), Gorontalo, Jawa Barat (Indramayu dan Tasikmalaya), Riau (Kampar dan Pekanbaru), Kalimantan Selatan (Banjar dan Banjarmasin).

Instrumen penelitian yang utama adalah para peneliti yang memiliki pengetahuan dasar dan wawasan mengenai Pendidikan Agama Islam (PAI) dan kebijakan pemda tentang baca tulis AlQur'an. Sebagai pendukung, para peneliti dilengkapi dengan instrument pengumpul data, yakni: pedoman wawancara, kuesioner, dan lembar periksa kelengkapan dokumen. Adapun sumber data penelitian adalah: aparat pemerintah daerah kabupaten/kota, dinas pendidikan, dan kepala kantor Kementerian Agama kabupaten/kota, kepala sekolah, guru dan anak didik SMPN.

Data yang terkumpul terlebih dahulu dilakukan klasifikasi, kategorisasi, dan entri data (untuk data yang bersifat kuantitatif). Kemudian dilakukan analisis (kuantitatif dan kualitatif) dengan teknik deskriptif yang bersifat naratif ataupun grafik.

\section{TEMUAN PENELITIAN}

\section{A. Bentuk Kebijakan Pemerintah Daerah tentang Baca- Tulis Al-Qur'an}

Berdasarkan temuan di lapangan bentuk-bentuk kebijakan pemerintah daerah yang menjadi landasan bagi penyelenggaraan kegiatan baca tulis Al-Qur'an terdiri atas: perda (peraturan daerah) provinsi, perda (peraturan daerah) kabupaten / kota, peraturan gubernur, peraturan bupati, dan instruksi kepala dinas.

Di Sulawesi Selatan, yakni Kabupaten Maros dan Gowa menggunakan Peraturan daerah sebagai dasar penyelenggaraan bacatulis Al-Qur'an. Di kabupaten Maros adalah Peraturan Daerah 
(PERDA) Kab. Maros No. 15 tahun 2005, tentang: 'Gerakan Bebas Buta Aksara dan Pandai Baca Al-Qur'an dalam wilayah kabupaten Maros yang kemudian ditindaklanjuti dengan peraturan Bupati. Di kabupaten Gowa adalah Perda Kabupaten Gowa No. 7 tahun 2003, tentang: Bebas Buta Aksara Al-Qur'an pada Pendidikan Tingkat Dasar dalam wilayah kabupaten Gowa. Untuk daerah Gorontalo, menggunakan Perda No. 22 Tahun 2005; Tentang Wajib Baca Tulis Al-Quran Bagi Siswa Yang Beragama Islam. Perda tersebut juga ditindaklanjuti dengan Keputusan Walikota Gorontalo No. 131 /21 /VII / 2010, tentang: Pembentukan Forum Komunikasi Instruktur Taman Pendidikan Al-Qur'an (FKITPQ) kota Gorontalo, Periode $2010-2015$.

Di Jawa Barat, yakni kabupaten Indramayu dan Tasikmalaya, kebijakannya berbentuk peraturan daerah dan peraturan bupati. Kabupaten Indramayu menggunakan Perda No. 2 tahun 2003, tentang: Wajib Belajar Madrasah Diniyah Awaliyah di Kabupaten Indramayu. Sementara kabupaten Tasikmalaya menggunakan Peraturan Bupati Tasikmalaya No: 4 tahun 2006, tentang: Pedoman Pembinaan dan Pengembangan Madrasah Diniyah di Kabupaten Tasikmalaya.

Di Kalimantan Selatan, yakni kota Banjarmasin dan kabupaten Banjar didasarkan pada peraturan daerah. Untuk Kota Banjarmasin mengacu Peraturan Daerah (Perda) Provinsi Kalimantan Selatan No. 3 tahun 2009 tentang Khatam Al-Qur'an bagi siswasiswi, yang menjadi dasar bagi penyelenggaraan muatan lokal dalam kurikulum sekolah. Dan untuk kabupaten Banjar telah ditetapkan dalam peraturan daerah (Perda) No. 4 tahun 2004, tentang: Khatam Al-Qur'an bagi peserta didik pada Pendidikan Dasar dan Menengah di Kabupaten Banjar.

Di Banten, yakni kabupaten Cilegon dan kabupaten Serang menggunakan bentuk peraturan daerah (perda) sebagai dasar penyelenggaraan kegiatan baca-tulis Al-Qur'an di sekolah bagi anak didik yang beragama Islam. Untuk kabupaten Serang ditetapkan peraturan daerah (Perda) No.1 Tahun 2006, dan Peraturan Bupati Serang No.10 tahun 2007, tentang: Tata kelola 
penyelenggaraan Wajib Belajar Madrasah Diniyah Awaliyah di Kabupaten Serang. Di Kabupaten Cilegon ditetapkan Perda No. 1 tahun 2008, tentang: Pelaksanaan Diniyah Awaliyah dan masih dalam pembahasan untuk dijabarkan dalam peraturan walikota.

Untuk Provinsi Riau, telah dikeluarkan Peraturan Gubernur (Pergub) Prov. Riau No. 32 Tahun 2008, tentang: Bebas Buta Aksara Al-Qur'an bagi murid Sekolah Dasar / Madrasah Ibtidaiyah yang beragama Islam di Provinsi Riau. Peraturan tersebut oleh pemerintah kabupaten Kampar ditindaklanjuti dengan instruksi Kepala Dinas Pendidikan Pemuda dan Olahraga Kabupaten Kampar Nomor: 420/DIKPORA/1577/2010, tentang: Kriteria Penerimaan Siswa Baru (PSB) Tahun 2010/ 2011. Dan untuk kota Pekanbaru, meskipun tidak ditindaklanjuti oleh pemerintah daerah, tetapi masyarakat menyambut kehadiran Peraturan Bupati tersebut dengan semangat yang tinggi untuk menyelenggarakan kegiatan baca-tulis Al-Qur'an.

Untuk Lombok Timur, bentuk kebijakan yang menjadi dasar kegiatan baca-tulis Al-Qur'an adalah Instruksi Kepala Dinas Pendidikan Pemuda dan Olahraga Kabupaten Lombok Timur, Nomor: 800/2079.08/Dik.2010, tentang: Membaca Al-Qur'an bagi siswasiswi di semua jenjang pendidikan pada sekolah negeri dan swasta di Kabupaten Lombok Timur.

Berdasarkan uraian tersebut di atas, terlihat bahwa landasan hukum bagi kebijakan pemerintah daerah dalam menyelenggarakan program baca tulis Al-Qur'an sangat beragam, demikian pula dengan nama kebijakan. Tentang nama kebijakan, ada yang secara tegas dalam konsiderans kebijakan menyebutkan baca tulis Al-Qur'an dan ada pula yang tidak. Meskipun demikian, dalam isinya dan maksudnya, kebijakan tersebut menyebutkan tentang pentingnya menyelenggarakan kegiatan baca tulis Al-Qur'an, terutama kepada pelajar yang beragama Islam. 


\section{B. Implementasi Kebijakan Pemda tentang baca-tulis Al- Qur'an di Sekolah}

Temuan yang penting tentang implementasi kebijakan di lapangan adalah bahwa sertifikat kemampuan baca-tulis Al-Qur'an menjadi salah satu persyaratan dalam seleksi penerimaan siswa baru pada jenjang sekolah menengah pertama, menengah atas dan menengah kejuruan; dan adanya aktivitas pembelajaran baca-tulis Al-Qur'an di sekolah dan di luar sekolah dengan media dan tenaga pengajar yang berasal dari sekolah maupun luar sekolah. Di bawah ini akan diuraikan temuan tersebut

1. Sertifikat kemampuan BTQ

Pada kabupaten/kota yang memiliki Peraturan Daerah (Perda) sebagai landasan hukum program Baca Tulis Al-Qur'an, maka salah satu persyaratan untuk mendaftar ke jenjang pendidikan SMP adalah memiliki sertifikat yang menerangkan kemampuan baca tulis Al-Qur'an. Kepala Dinas Pendidikan menginstruksikan kepada setiap sekolah (SMP) Negeri dan Swasta agar penerimaan siswa baru (PSB) dilakukan dengan memperhatikan kemampuan dan sertifikat baca tulis Al-Qur'an sebagai persyaratan.

Hal tersebut dipraktekkan oleh setiap sekolah (SMP) dengan memberikan formulir pendaftaran hanya kepada calon siswa yang memiliki sertifikat kemampuan membaca dan menulis huruf $\mathrm{Al}$ Qur'an. Di samping bukti fisik sertifikat, beberapa sekolah ada yang juga melakukan test baca tulis Al-Qur'an untuk mengetahui secara otentik kemampuan calon siswa. Mereka hanya menerima siswa yang telah mampu membaca Al-Qur'an dengan tingkat kemahiran tertinggi. Sehingga dalam prakteknya, siswa yang tidak atau masih kurang mampu dalam membaca dan menulis Al-Qur'an tidak dapat masuk di sekolah favorit, seperti: di SMP RSBI Maros, Sekolah Unggulan SMPN 2 Selong.

Bagi sekolah (SMP) yang kurang favorit atau berada pada standard mutu menengah dan bawah, persyaratan sertifikat kemampuan baca tulis Al-Qur'an juga menjadi persyaratan masuk; tetapi mereka tetap menerima siswa yang belum memiliki ser- 
tifikat, atau belum mahir dan mampu mengaji. Dan dalam penempatan kelas, siswa yang tidak memiliki sertifikat dan belum mampu baca-tulis Al-Qur'an tersebut ditempatkan pada kelas tertentu dan mendapat tambahan pelajar baca-tulis Al-Qur'an. Mereka juga diharuskan untuk mengikuti ujian sertifikasi untuk mendapatkan sertifikat kemampuan baca-tulis Al-Qur'an. Para orang tua turut menandatangani dan menyatakan kesiapan untuk mendorong anak mereka belajar baca tulis Al-Qur'an.

Pada kabupaten / kota yang belum memiliki kebijakan daerah tentang baca tulis Al-Qur'an, tetapi pada tingkat provinsi ada kebijakan Gubernur atau peraturan daerah provinsi tentang bacatulis Al-Qur'an; maka sekolah (SMP) tidak memiliki keharusan untuk memberlakukan persyaratan kemampuan baca - tulis AlQur'an sebagai persyaratan masuk. Dinas pendidikan kabupaten / kota tidak menindaklanjutinya ke tingkat sekolah. Meskipun demikian beberapa sekolah ada yang melakukan pembelajaran baca tulis Al-Qur'an di sekolah, dan menyeleksi murid baru berdasarkan kemampuan baca-tulis Al-Qur'an.

Selain bentuk peraturan daerah (PERDA), ada pula Instruksi atau Surat Perintah Kepala Dinas Pendidikan, tentang pelaksanaan penerimaan siswa baru. Beberapa daerah seperti Kampar Kepala Dinasnya menginstruksikan agar penerimaan siswa baru mensyaratkan kemampuan baca-tulis Al-Qur'an. Di daerah kabupaten Lombok Timur, Kepala Dinasnya menginstruksikan agar setiap sekolah mulai dari jenjang pendidikan dasar hingga jenjang menengah baik negeri maupun swasta menekankan agar siswasiswinya dapat membaca Al-Qur'an secara fasih. Disamping itu, sebelum memulai pelajaran agar diawali terlebih dahulu dengan membaca Al-Qur'an.

2. Aktivitas Pembelajaran BTQ di sekolah dan luar sekolah

Kebijakan pemerintah daerah tentang baca tulis Al-Qur'an menuntut agar setiap anak sekolah yang beragama Islam dapat membaca dan menulis huruf Al-Qur'an. Oleh karena itu dilakukan 
serangkaian proses belajar mengajar kepada anak didik baik di sekolah maupun di luar sekolah.

Pada sekolah-sekolah unggulan yang menerapkan persyaratan masuk dengan sertifikat dan tes baca tulis Al-Qur'an, masih tetap dilakukan proses pendalaman belajar mengajar mengaji, meskipun secara umum semua siswanya (yang diterima melalui seleksi murid baru) sudah dapat membaca Al-Qur'an.

Di SMPN 2 Maros (RSBI), pembelajaran mengaji dilakukan untuk pendalaman dan mempermahir tajwid, makhraj, dan tilawah. Khusus tilawah di datangkan guru dari luar sekolah yang pernah menjuarai MTQ. Gaji guru / ustadz tersebut dibayarkan oleh sekolah. Kegiatan tersebut dilakukan dalam konteks kegiatan ekstra-kurikuler di sekolah. Pada sekolah yang lain, penyelenggaraan kegiatan baca-tulis Al-Qur'an dilakukan dalam konteks pengembangan diri siswa dengan alokasi waktu 2 (dua) jam perminggu. Sementara pada sekolah yang lain, ada pula yang pelaksanaannya berdasarkan muatan lokal.

Deskripsi penyelenggaraan kegiatan baca-tulis Al-Qur'an di sekolah dapat digambarkan melalui tabel di bawah ini:

Tabel. Bentuk Penyelenggaraan BTQ di sekolah - sekolah

\begin{tabular}{|c|c|c|}
\hline No. & Bentuk Pembelajaran BTQ & Keterangan \\
\hline 1 & Ekstrakurikuler & $\begin{array}{l}\text { Dilakukan pada hari Sabtu, atau pada } \\
\text { jam sesudah jam belajar. Biasanya BTQ } \\
\text { menjadi salah satu dari beberapa macam } \\
\text { paket kegiatan ekstra-kurikuler; dan } \\
\text { bersifat wajib bagi siswa yang belum } \\
\text { memiliki dan belum mampu/lancer } \\
\text { membaca Al-Qur'an }\end{array}$ \\
\hline 2 & Muatan Lokal & Prakteknya mirip dengan ekstrakurikuler. \\
\hline 3 & Pengembangan Diri & Prakteknya mirip dengan ekstrakurikuler. \\
\hline
\end{tabular}

Pilihan bentuk penyelenggaraan BTQ di sekolah di luar jam pelajaran pendidikan agama Islam (ekskul, mulok, atau pengembangan diri) sepenuhnya menjadi wewenang sekolah. Alasan yang umum dikemukakan oleh GPAI dan Kepala Sekolah, adalah: kurangnya jumlah jam pelajaran pendidikan agama di sekolah, dan 
penambahan jam mengajar bagi guru (termasuk guru NON-PAI) yang kurang jumlah jam mengajar untuk memenuhi standar minimal dan untuk kepentingan kredit point.

Selain di sekolah anak didik juga belajar di luar sekolah, baik di rumah melalui keluarga maupun di masjid, surau, majlis taklim, madrasah diniyah, dan lain-lain. Berdasarkan angket, maka tempat belajar dan siapa yang mengajari anak-anak sekolah tersebut dengan kemampuan baca - tulis Al-Qur'an disajikan dalam tabel:

Tabel tempat siswa-siswi SMP belajar BTQ

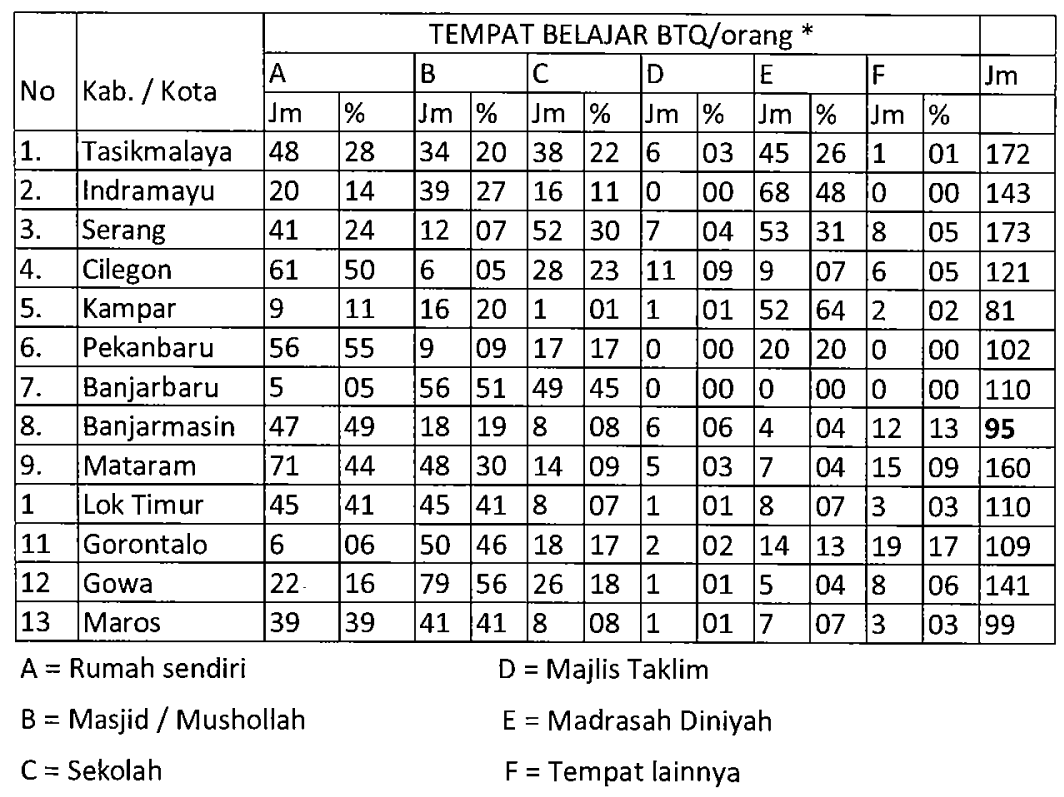

Berdasarkan tabel tersebut di atas, dapat dilihat bahwa mayoritas yang menjadi tempat belajar baca-tulis Al-Qur'an pelajar SMP adalah: rumah, mesjid/mushola dan Madrasah Diniyah. Dua tempat belajar yang pertama yakni rumah dan musholla merupakan (diasumsikan sebagai) tempat konvensional yang sudah umum digunakan oleh masyarakat muslim di Indonesia sejak dulu, sementara tempat belajar ketiga yakni Madrasah Diniyah merupakan tempat belajar yang secara imperatif merupakan sistem pendukung dari kebijakan pemerintah daerah. 
Dari data tersebut di atas, terlihat bahwa kota Indramayu (68/143 orang), Serang (53/173) dan kabupaten Kampar (52/81 orang) merupakan kota dengan jumlah prosentase siswa terbesar belajar dari Madrasah Diniyah dibanding tempat lainnya. Hal ini mendukung skor efektivitas implementasi kebijakan baik pada aspek implementasi tujuan ataupun pada aspek implementasi sistem pendukung. Sementara kota Tasikmalaya menunjukkan perimbangan tempat belajar antara Madrasah Diniyah dengan Rumah sebagai tempat yang banyak dijadikan tempat belajar oleh siswa-siswi SMP. Hal ini menunjukkan disamping aspek efektivitas kebijakan, aspek kultur masyarakat juga sangat dominan dalam membangun kemampuan baca tulis Al-Qur'an kepada pelajar.

Di samping Tasikmalaya, daerah dengan tempat belajar konvensional yakni rumah dan musholah adalah: Cilegon, Gowa, Maros, Pekanbaru, Banjarbaru, Banjarmasin, Mataram, Lombok Timur, dan Gorontalo.

Hal tersebut menunjukkan masih kurangnya ketersediaan Madrasah Diniyah, sebagai tempat belajar baca-tulis Al-Qur'an. Bagi daerah dengan skor efektivitas kebijakan tinggi, hal ini menunukkkan bahwa implementasi sistem pendukung kebijakan masih sangat minim. Hal tersebut juga menunjukkan bahwa budaya keagamaan pada masyarakat setempat merupakan salah satu faktor utama pendukung efektivitas kebijakan pemerintah daerah, dan kemampuan pelajar dalam baca-tulis Al-Qur'an. Analisis tersebut, sejalan dan didukung pula oleh fakta tentang ustadz sumber belajar siswa-siswi di lokasi penelitian, dimana mereka lebih banyak di ajar oleh pihak keluarga dan ustadz dari Musholah, seperti terlihat pada tabel di bawah ini.

Tabel Ustadz yang mengajari siswa - siswi SMP

\begin{tabular}{|c|c|c|c|c|c|c|c|c|c|c|c|c|}
\hline \multirow{3}{*}{ No } & \multirow{3}{*}{ Kab. / Kota } & \multicolumn{10}{|c|}{ ASAL USTADZ BTQ * } & \multirow{3}{*}{$\mathrm{Jm}$} \\
\hline & & \multicolumn{2}{|l|}{$A$} & \multicolumn{2}{|l|}{$\mathrm{B}$} & \multicolumn{2}{|l|}{ C } & \multicolumn{2}{|l|}{$\mathrm{D}$} & \multicolumn{2}{|l|}{$E$} & \\
\hline & & $\mathrm{Jm}$ & $\%$ & $\mathrm{Jm}$ & $\%$ & $\mathrm{Jm}$ & $\%$ & $\mathrm{Jm}$ & $\%$ & $\mathrm{Jm}$ & $\%$ & \\
\hline 1. & Tasikmalaya & 51 & 30 & 36 & $2 \overline{1}$ & 34 & 20 & 43 & 26 & 4 & 02 & 168 \\
\hline 2. & Indramayu & 25 & 17 & 15 & 10 & 38 & 26 & 70 & 47 & 0 & 00 & 148 \\
\hline 3. & Serang & 32 & 21 & 42 & 27 & 15 & 10 & 55 & 35 & 11 & 07 & 155 \\
\hline
\end{tabular}




\begin{tabular}{|l|l|l|l|l|l|l|l|l|l|l|l|l|}
\hline 4. & Cilegon & 57 & 45 & 24 & 19 & 13 & 10 & 22 & 17 & 10 & 08 & 126 \\
\hline 5. & Kampar & 10 & 12 & 1 & 01 & 15 & 19 & 53 & 65 & 2 & 02 & 81 \\
\hline 6. & Pekanbaru & 40 & 40 & 17 & 17 & 17 & 17 & 21 & 21 & 5 & 05 & 100 \\
\hline 7. & Banjar & 3 & 03 & 78 & 90 & 2 & 02 & 4 & 05 & 0 & 00 & 87 \\
\hline 8. & Banjarmasin & 30 & 32 & 9 & 10 & 25 & 27 & 12 & 13 & 18 & 19 & 94 \\
\hline 9. & Mataram & 68 & 41 & 19 & 12 & 49 & 30 & 6 & 04 & 22 & 13 & 164 \\
\hline 10. & Lok Timur & 43 & 38 & 13 & 12 & 38 & 34 & 14 & 13 & 4 & 04 & 112 \\
\hline 11. & Gorontalo & 6 & 06 & 12 & 11 & 54 & 50 & 17 & 16 & 19 & 18 & 108 \\
\hline 12. & Gowa & 18 & 13 & 24 & 17 & 84 & 60 & 5 & 04 & 9 & 06 & 140 \\
\hline 13. & Maros & 38 & 38 & 13 & 13 & 36 & 36 & 9 & 09 & 4 & 04 & 100 \\
\hline
\end{tabular}

$$
\begin{array}{ll}
A=\text { Keluarga (orang tua/kakak) } & \text { D = Ustadz Madrasah Diniyah } \\
B=\text { Guru sekolah } & E=\text { Lain -lain } \\
C=\text { Ustadz Masjid / Mushollah) } &
\end{array}
$$

\section{Faktor Pendukung dan Penghambat}

Berdasarkan temuan penelitian, beberapa pola dapat diidentifikasi sebagai faktor-faktor pendukung dan penghambat implementasi kebijakan pemerintah daerah dalam mengimplementasikan kebijakan baca-tulis Al-Qur'an. Secara detail faktor-faktor tersebut dapat diuraikan sebagai berikut:

1) Alokasi anggaran pemerintah daerah (APBD) terhadap kegiatan baca-tulis Al-Qur'an. Beberapa daerah mengalokasikan anggaran terhadap kegiatan baca-tulis Al-Qur'an, yang secara operasional diperuntukkan bagi kegiatan evaluasi dan ujian sertifikasi kemampuan baca-tulis Al-Qur'an; reward dan insentif kepada para ustadz, pendirian tempat belajar seperti TPQ TPA, Madrasah Diniyah, mengadaan sumber belajar dan media pembelajaran. Pada daerah ini, aktivitas pembelajaran baca-tulis Al-Qur'an berlangsung secara efektif, baik di tengah masyarakat maupun secara formil. Alokasi anggaran pemerintah daerah (APBD) untuk kegiatan pendidikan baca-tulis Al-Qur'an masih sangat rendah, dan secara umum masih diambil dari alokasi anggaran pembangunan pendidikan, kesejahteraan rakyat (kesra) maupun pembangunan mental, spiritual. Sebagai gambaran, insentif kepada para ustadz yang mengajar baca-tulis Al-Qur'an, ada yang hanya Rp. 200.000 
pertahun (yang paling rendah) hingga Rp. 300.000 perbulan (yang paling tinggi). Demikian pula dengan dukungan media dan sumber belajar yang masih banyak meng-andalkan swadaya masyarakat.

2) Keterlibatan dan Partisipasi Sumber Daya Manusia (SDM) kantor kementerian agama di daerah. Seluruh daerah yang mengeluarkan kebijakan tentang baca-tulis Al-Qur'an, peran secara inklusif para guru pendidikan agama (GPAI), pengawas guru pendidikan agama, penyuluh agama, serta staf kementerian agama di daerah sangat menonjol. Secara umum mereka menjadi tenaga pengajar (ustadz) yang mengajarkan baca-tulis Al-Qur'an di sekolah dan di luar sekolah. Pengawas GPAI, turut terlibat dalam kegiatan monitoring dan evaluasi kebijakan yang dilakukan secara paralel dengan tugas-tugas kedinasan sebagai pengawas. Mereka membuat laporan kepada kepala kantor kementerian agama dan kepada tim kerja implementasi baca-tulis Al-Qur'an di daerah.

3) Partisipasi Sekolah. Secara resmi dan terjadwal mencantumkan kegiatan baca-tulis Al-Qur'an dalam kegiatan ekstrakurikuler. Pengajaran baca-tulis Al-Qur'an tidak dilakukan secara integratif dalam mata pelajaran pendidikan agama Islam, tetapi di luar jam pelajaran tersebut. Sekolah juga secara konsisten dan fleksibel menerapkan persyaratan sertifikat kemampuan bacatulis Al-Qur'an sebagai persyaratan penerimaan murid/siswa baru. Kepada siswa yang masih kurang lancer membaca dan menulis AlQur'an, maka sekolah akan memberikan pelajaran tambahan di luar jam pelajaran sekolah.

4) Tantangan teknologi, media informasi dan hiburan. Beberapa orang tua mengeluhkan anak-anak mereka yang tidak belajar baca-tulis Al-Qur'an pada saat ada tayangan Televisi yang menarik. Anak mereka lebih menyukai, dan memilih untuk menonton Televisi dan menunda untuk tidak mengikuti pembelajaran. Hal serupa juga dialami oleh ustadz yag mengajar. Menurut ustadz, beberapa anak pada hari tertentu karena ada acara televisi yang menarik, tidak hadir belajar baca-tulis Al-Qur'an. Meskipun demikian, ustadz tetap memandang bahwa anak-anak tersebut tetap mau dan bersedia untuk tetap belajar baca-tulis Al-Qur'an. 
5) Sikap mental dan kondisi ekonomi orang tua. Beberapa orang tua yang anaknya masih kurang lancar dan belum memperoleh sertifikat kemampuan baca-tulis Al-Qur'an, menandatangani pernyataan kesanggupan dan kesediaan di hadapan pimpinan sekolah atau guru agama Islam di sekolah untuk membimbing anaknya hingga mampu. Meskipun demikian, kesibukan orang tua membuat mereka kurang ketat memberikan perhatian kepada anak-anak mereka untuk rajin belajar baca-tulis Al-Qur'an.

6) Partisipasi masyarakat. Kebanyakan kasus yang ditemui di lokasi penelitian menunjukkan bahwa penyediaan tempat belajar, sumber dan media pembelajaran disediakan secara sukarela oleh masyarakat. Beberapa ustadz juga ada yang menyatakan bahwa mereka mengajar baca-tulis Al-Qur'an bukan semata-mata karena mendapat insentif atau surat tugas dari pemerintah atau dari sekolah. Beberapa ustadz tersebut menyatakan bahwa mereka telah mengajar baca-tulis Al-Qur'an sejak sebelum adanya kebijakan baca-tulis Al-Qur'an di daerah tersebut. Beberapa orang kepala sekolah juga menyatakan bahwa kewajiban belajar mengaji bagi siswa-siswi telah dilakukan sebelum lahirnya kebijakan dari pemerintah daerah. Mereka perpendapat bahwa tanpa kebijakan pemerintah daerah tentang baca-tulis Al-Qur'an, kegiatan pembelajaran baca tulis Al-Qur'an dapat terlaksana dengan lancar.

\section{ANALISIS HASIL PENELITIAN}

\section{A. Peran Kementerian Agama di Daerah}

Karena eksistensinya sebagai lembaga yang memiliki tugas pokok dan sumber daya manusia keagamaan, maka secara struktural formil, umumnya kementerian agama kabupaten atau kota diposisikan sebagai pembina, salah satu staf ketua, atau menjadi anggota tim dalam sosialisasi kebijakan kepada masyarakat dan stake holders pendidikan. Secara fungsional, guru pendidikan agama Islam, Penyuluh dan Pengawas pendidikan Islam juga mendapat tugas tambahan untuk ikut menyukseskan kebijakan. Para guru ikut mengajar di sekolah, penyuluh mengajar di majlis taklim, atau TPA/TPQ, dan pengawas ikut mengawasi 
penyelenggaraan kegiatan baca-tulis Al-Qur'an di sekolah serta memonitor pelaksanaan penerimaan murid baru yang mensyaratkan kemampuan baca-tulis Al-Qur'an. Pada daerah yang menyelenggarakan sertifikasi kemampuan baca-tulis Al-Qur'an, kementerian agama di daerah dilibatkan secara penuh.

Posisi Kementerian Agama kabupaten atau kota lebih maksimal dalam mendukung dan terlibat dalam penyelenggaraan kebijakan baca tulis Al-Qur'an di daerah dibandingkan dengan posisi kantor wilayah kementerian agama di tingkat provinsi. Hal ini karena kebijakan baca tulis Al-Qur'an pada tingkat provinsi kurang terimplementasi secara baik dan tidak ditindaklanjuti oleh pemerintah kabupaten atau kota.

\section{B. Peran Budaya Lokal dan Tanggapan Stakeholders}

Berdasarkan gambaran hasil penelitian yang diperoleh pada setiap daerah penelitian, peran budaya daerah setempat sangat dominan dalam mewarnai pelaksanaan kegiatan baca-tulis AlQur'an bagi anak dan pelajar. Budaya malu tidak bisa membaca dan menulis Al-Qur'an di kalangan keluarga muslim menjadi salah satu faktor utama berkembangnya aktivitas belajar mengajar bacatulis Al-Qur'an di masyarakat dan di sekolah.

Meskipun demikian, banyak tokoh masyarakat, tokoh agama, dan tokoh pendidikan di daerah memandang bahwa pengaruh budaya global yang berkembang melalui media televisi dan internet sangat besar terhadap budaya masyarakat lokal. Kebiasaan mengaji yang bersifat umum di masyarakat sedikit-demi sedikit mulai terpengaruh oleh perkembangan budaya global dan meterialism. Budaya mengaji di masa kanak-kanak mulai terpengaruh. Sebagian kecil anak-anak dan orang tua yang sibuk dengan tantangan kerja, menjadikan kebiasaan belajar mengaji di masa kecil menjadi kurang kuat.

Dalam perspektif ini, maka formalisasi aktivitas baca tulis AlQur'an melalui kebijakan pemerintah daerah dengan mewajibkan siswa-siswi yang beragama Islam untuk mampu membaca dan menulis Al-Qur'an sejak dini sangat bermanfaat. Dan secara umum, 
masyarakat muslim menerima dengan baik adanya kebijakan pemerintah daerah tentang baca-tulis Al-Qur'an. Mereka berpendapat bahwa kebijakan tersebut sejalan dengan pandangan mereka tentang kewajiban mempelajari Al-Qur'an bagi kaum muslimin. Kalangan pendidik dan praktisi pendidikan juga menerima dengan baik kebijakan tersebut.

\section{Sertifikasi dan Sistem Pembelajaran BTQ}

Sertifikat kemampuan baca-tulis dan khatam Al-Qur'an sebagai bukti formil yang dipegang oleh siswa dan menjadi bahan persyaratan untuk mendaftar pada jenjang pendidikan yang lebih tinggi, merupakan praktek yang positif dalam rangka memelihara dan mendorong semangat dan kebiasaan belajar mengaji atau baca-tulis Al-Qur'an pada masyarakat muslim. Sistem sertifikasi tersebut telah diimplementasikan pada beberapa daerah yang memiliki kebijakan tentang baca-tulis Al-Qur'an, yakni: Maros, Gowa, Gorontalo, Banjarbaru, Tasikmalaya, Indramayu, dan Serang. Sistem penyelenggaraan sertifikasi dan evaluasi belajar baca-tulis Al-Qur'an di daerah tersebut berbeda-beda dan masih sangat beragam, dengan standard tes yang dibuat oleh masing masing daerah dengan melibatkan stakeholders yang relevan.

Demikian pula dengan standar kompetensi untuk tiap jenjang pendidikan (dasar, menengah dan tinggi); sistem evaluasinya, dan termasuk institusi yang bertanggung jawab. Kantor Kementerian Agama di Daerah secara formil belum mengurus hal tersebut secara sistematis, dan hanya terlibat secara personal.

\section{PENUTUP}

\section{A. Kesimpulan}

1. Bentuk kebijakan pemerintah daerah di Indonesia yang mengatur tentang ketentuan baca tulis Al-Qur'an bagi siswa/ pelajar sangat beragam. Beberapa daerah kebijakannya berbentuk peraturan daerah (PERDA), ada juga yang berbentuk peraturan bupati (PERBUP), peraturan gubernur (PERGUB), dan ada pula yang menggunakan instruksi kepala dinas pendidikan. 
2. Bentuk implementasi kebijakan pemerintah daerah tentang baca-tulis Al-Qur'an di lapangan penelitan adalah adanya sertifikasi kemampuan baca-tulis Al-Qur'an yang kemudian dijadikan sebagai salah satu persyaratan masuk dalam pene-rimaan siswa baru pada jenjang sekolah menengah pertama, menegah atas, dan menengah kejuruan. Pada sisi lain, aktivitas pembelajaran bacatulis Al-Qur'an pada daerah-daerah yang memiliki kebijakan pemerintahdaerah tersebut, meningkat dan beragam, baik diselenggarakan di sekolah pada jam ekstra-kurikuler, maupun di luar sekolah, dengan tenaga pengajar yang berasal dari sekolah atau pun dari luar sekolah. Posisi dan peran budaya lokal bersinergi dengan kebijakan pemerintah daerah dalam penyelenggaraan kegiatan baca-tulis Al-Qur'an di daerah. Posisi kantor kementerian agama kabu-paten juga sangat penting dalam mendukung dan menunjang implementasi kebijakan tersebut.

3. Tantangan dan hambatan dalam implementasi kebijakan pemerintah tentang baca tulis Al-Qur'an adalah konsistensi dan komitment pemerintah daerah dalam mengalokasikan anggaran untuk pembanguna infrastruktur pendidikan dan pembinaan ustadz. Beberapa daerah yang sudah mengeluarkan kebijakan tentang baca-tulis Al-Qur'an belum mengalokasi anggaran yang real dalam kebijakan anggaran pembangunan daerahnya (APBD).

\section{B. Rekomendasi}

Penelitian ini merekomedasikan kepada Kementerian Agama RI agar memberikan respon yang positif terhadap pemberlakuan "sertifikat baca tulis Al-Qur'an dan kemampuan baca tulis AlQur'an bagi siswa-siswi muslim sebagai persyaratan pendaftaran siswa baru pada sekolah umum (SMP, SMA, SMK)", dengan:

1) Mendukung kebijakan sertifikasi kemampuan baca tulis $\mathrm{Al}$ Qur'an yang dilakukan di daerah dengan melakukan pengkajian untuk merumuskan sistem sertifikasi kemampuan baca tulis AlQur'an bagi siswa muslim; 
2) Memberikan arahan dan dukungan kepada Kementerian Agama kabupaten/kota untuk turut mendukung implementasi kebijakan baca-tulis Al-Qur'an di wilayahnya masing-masing;

3) Melakukan pembinaan dan peningkatan kualitas dan kompetensi Guru Pendidikan Agama Islam (GPAI) di sekolah, Penyuluh, dan Pengawas agar mempunyai kompetensi tambahan untuk mengajarkan baca-tulis Al-Qur'an, di samping tugas pokok mengajarkan mata pelajaran Pendidikan Agama Islam;

4) Mengkaji, dan merumuskan standarisasi dan prosedur Evaluasi Kemampuan Baca Tulis AI-Qur'an bagi siswa jenjang pendidikan SD, SMP, SMA;

\section{SUMBER BACAAN}

Anshari, Endang Saifudin (1996): Pokok-pokok Pikiran tentang Islam. Jakarta, Usaha Enterprise.

Azra, Azyumardi (2002): Pendidikan Islam: Tradisi dan Modernisasi menuju Milenium Baru. Jakarta, Logos.

Marimba, Ahmad D (1980): Pengantar Filsafat Pendidikan Islam. Bandung, Al-Ma'arif.

Peraturan Mendiknas Nomor 22 tahun 2006, tentang Standard Kompetensi dan Kompetensi Dasar (SKKD).

Undang-undang No. 20 tahun 2003, tentang: Sistem Pendidikan Nasional. UU No. 32 tahun 2004 tentang Pemerintahan Daerah. 